\title{
IRON AS A DISTURBING FACTOR IN THE DETERMINATION OF PHOSPHATE BY THE MOLYBDENUM BLUE METHOD
}

\author{
By \\ ARMi KaILA \\ University of Helsinki, Department of Agricultural Chemistry
}

Received 2nd July 1954

The colorimetric determination of phosphate by the molybdenum blue method has several weak points, among which the disturbance caused by the presence of even a low concentration of iron in the solution is one of the most serious reasons for unsatisfactory results. In the largely employed modification of the method by Truog and Meyer (6) ferric iron in as low concentrations as $4-6$ ppm interferes with the determination. Dyer and Wrenshall (2) report that for accurate results the concentration of ferric iron should not exceed about $1 \mathrm{ppm}$. Also it has been found that the ferrous iron rather markedly affects the results, at least under certain conditions $(1,2)$.

Several procedures have been proposed for the elimination of the disturbing effect of iron. Truog and Meyer (6) and Tschopp (7) reduced the ferric iron in the solution into ferrous form by metallic cadmium, or potassium monosulphite, respectively. TISCHER (5) tried to mask ferric iron by potassium cyanide, but this procedure was suitable only for low iron concentrations. Iron has been removed from the solution e.g. by potassium ferrocyanide (9), by the electrolysis (8), or by the precipitation with oxine (3).

All these methods are laborious, or complicate the interpretation of the results by the effects of the additional substances on the colour development. Therefore, it seemed to be desirable to study whether the reaction itself could be modified to be less sensitive to the influence of iron. Because it is important that the procedure is as simple and as rapid as possible, extra manipulations were avoided and the experimentation was concentrated only to the possibilities offered by changes in the amount of the reducing agent and in the concentrations of the acid and ammonium molybdate in the reagent. 


\section{Amount of the reducing agent}

Truog and Meyer (6) used 6 drops or about $0.25 \mathrm{ml}$ of a $2.5 \% \mathrm{SnCl}_{2} \cdot 2 \mathrm{H}_{2} \mathrm{O}$ solution for the reduction of the phosphomolybdic acid complex in $100 \mathrm{ml}$ of solution containing $100 \mathrm{mg}$ of ammonium molybdate and 40 me of sulphuric acid. Under these conditions the interference of ferric iron appears as a rapid fading of the blue colour, or as a partial prevention of the colour development. This is supposed to be due to an increase in the oxidation-reduction potential of the phosphomolybdic acid-molybdenum blue and stannous ion systems (5). Sмiтh et al. (4) observed that stannic ions cause the fading of the colour to take place sooner, and in higher concentrations, inhibit the maximum colour development, even in the presence of normal amounts of stannous ions. These authors supposed that the iron interference might be due, at least in part, to the rapid oxidation of stannous tin to the stannic condition by the ferric iron. It seemed to be possible to avoid the fading effect of ferric iron by increasing the amount of stannous chloride or bydecreasing the need of the reducing agent, it is by diluting the sample.

Some experiments were performed in order to study these problems. Solutions containing various amounts of phosphorus as potassium monophosphate and ferric iron as ferric sulphate were analyzed by the method of Truog and Meyer. The amounts of stannous chloride added to $100 \mathrm{ml}$ of the solutions were $0.25 \mathrm{ml}, 0.5 \mathrm{ml}$, $1.0 \mathrm{ml}, 1.5 \mathrm{ml}$, and $2.0 \mathrm{ml}$, or $1,2,4,6$, and 8 times the amount used in the original method. The density of the colour was measured 15 minutes after the reduction by a Lumetron photoelectric colorimeter Model 402-E employing the monochromatic light filter which has its transsmision peak at $660 \mathrm{~m} \mu$.

The phosphorus concentration found in the solutions containing iron was calculated on the basis of standard series reduced by respective amounts of stannous chloride. This was necessary, because the level of the colour intensity became significantly higher when the amount of stannous chloride was increased, in the solutions of 0.10 and $0.25 \mathrm{ppm}$ of phosphorus up to $2.0 \mathrm{ml}$, in solutions of 0.50 and $1.00 \mathrm{ppm}$ of phosphorus only up to $1.0 \mathrm{ml}$ of the reducing agent. This increase in the density appeared also in the iron solutions and, except in the solutions containing the highest iron concentrations, the density values were markedly greater even in the $0.5 \mathrm{ml}$ series than in the $0.25 \mathrm{ml}$ series. Consequently, the interference of ferric iron cannot be avoided by adding a larger amount of the reducing agent only to the solutions suspected to contain iron.

According to the results in Table 1, the phosphorus values found for the various solutions reduced by $0.25 \mathrm{ml}$ of stannous chloride are both relatively and absolutely the lower the higher the iron concentration. The errors caused by equal amounts of iron are the higher the higher the phosphorus concentration. Thus the disturbing influence of ferric iron may be largely decreased by diluting the solution. For example, if the solution containing $1.00 \mathrm{ppm}$ of phosphorus and $100 \mathrm{ppm}$ of iron is diluted twofold, the error which was $61 \%$ drops to $28 \%$. A dilution in the ratio 1: 4 decreases the error to $12 \%$, and if the dilution is in the ratio of 1 : 10 , or the phosphorus concentration becomes $0.10 \mathrm{ppm}$ and the iron concentration $10 \mathrm{ppm}$, no interference of iron is found, at least according to these results. 
Table 1. Phosphorus found in the solutions containing ferric iron when reduced by increasing amounts of stannous chloride

\begin{tabular}{|c|c|c|c|c|c|c|}
\hline \multirow{2}{*}{$\begin{array}{c}\mathrm{P} \\
\text { in solution } \\
\mathrm{ppm}\end{array}$} & \multirow{2}{*}{$\begin{array}{c}\text { Stannous } \\
\text { chloride } \\
\mathrm{ml}\end{array}$} & \multirow[b]{2}{*}{5} & \multicolumn{3}{|c|}{ Ferric iron, ppm } & \multirow[b]{2}{*}{100} \\
\hline & & & 10 & 25 & 50 & \\
\hline \multirow[t]{5}{*}{0.10} & 0.25 & 0.09 & 0.10 & 0.10 & 0.10 & 0.08 \\
\hline & 0.5 & 0.09 & 0.09 & 0.09 & 0.09 & 0.09 \\
\hline & 1.0 & 0.09 & 0.09 & 0.08 & 0.08 & 0.08 \\
\hline & 1.5 & 0.09 & 0.09 & 0.08 & 0.08 & 0.07 \\
\hline & 2.0 & 0.09 & 0.09 & 0.08 & 0.07 & 0.05 \\
\hline \multirow[t]{5}{*}{0.25} & 0.25 & 0.23 & 0.23 & 0.22 & 0.20 & 0.17 \\
\hline & 0.5 & 0.25 & 0.24 & 0.23 & 0.23 & 0.17 \\
\hline & 1.0 & 0.24 & 0.24 & 0.23 & 0.22 & 0.17 \\
\hline & 1.5 & 0.24 & 0.24 & 0.22 & 0.22 & 0.20 \\
\hline & 2.0 & 0.25 & 0.25 & 0.23 & 0.22 & 0.21 \\
\hline \multirow[t]{5}{*}{0.50} & 0.25 & 0.47 & 0.48 & 0.42 & 0.36 & 0.30 \\
\hline & 0.5 & 0.50 & 0.47 & 0.48 & 0.39 & 0.36 \\
\hline & 1.0 & 0.50 & 0.50 & 0.49 & 0.47 & 0.32 \\
\hline & 1.5 & 0.50 & 0.49 & 0.49 & 0.47 & 0.45 \\
\hline & 2.0 & 0.50 & 0.50 & 0.49 & 0.48 & 0.46 \\
\hline \multirow[t]{5}{*}{1.00} & 0.25 & 0.95 & 0.86 & 0.70 & 0.49 & 0.39 \\
\hline & 0.5 & 0.97 & 0.96 & 0.96 & 0.72 & 0.61 \\
\hline & 1.0 & 0.99 & 0.98 & 0.97 & 0.94 & 0.69 \\
\hline & 1.5 & 0.99 & 0.99 & 0.99 & 0.98 & 0.93 \\
\hline & 2.0 & 1.00 & 1.00 & 0.99 & 0.97 & 0.95 \\
\hline
\end{tabular}

An increase in the amount of stannous chloride considerably decreased the iron interference, particularly in the solutions of higher concentrations of phosphorus. The improvement in the solutions containing $0.25 \mathrm{ppm}$ of phosphorus was less marked, and in the solutions of $0.10 \mathrm{ppm}$ the effect was negative. Thus e.g. in the solutions containing $50 \mathrm{ppm}$ of iron an increase in the amount of stannous chloride from $0.25 \mathrm{ml}$ to $2.0 \mathrm{ml}$ increased the error in the solutions of $0.10 \mathrm{ppm}$ of phosphorus from 0 to 30 per cent but decreased it in the phosphorus solution of $1.00 \mathrm{ppm}$ from 51 to 3 per cent. This irregularity is not quite easy to explain, at least, as long as the ceruleomolybdate reaction of phosphate is not thoroughly understood. Yet, an examination of the effect of ferrous iron on the colour intensity may somewhat elucidate this problem.

In solutions containing 0,5 , or $10 \mathrm{ppm}$ of ferrous iron as ferrous sulphate the phosphorus values measured about 15 minutes after the addition of $0.25 \mathrm{ml}$ of stannous chloride were as follows:

Ferrous iron

ppm

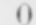

5

10
Phosphorus found in solution

ppm

$\begin{array}{lllll}0 & 0.10 & 0.25 & 0.50 & 1.00 \\ 5 & 0.08 & 0.21 & 0.44 & 0.93 \\ 0 & 0.07 & 0.20 & 0.42 & 0.92\end{array}$


As compared to the effect of ferric iron the ferrous ions seemed to cause some what lower phosphorus values. The higher the concentration of ferrous iron the higher were the errors, e. g. in a solution containing $0.50 \mathrm{ppm}$ of phosphorus the values found in the presence of 25,50 , and $100 \mathrm{ppm}$ of ferrous iron were $0.38,0.36$, and $0.33 \mathrm{ppm}$, respectively. These results are in accordance with those found by CHAPman (1) and Dyer and Wrenshall (2). If higher amounts of stannous chloride were applied the concentrations of phosphorus found in the solutions containing $10 \mathrm{ppm}$ of ferrous iron were even more lower than those measured when the normal amount of the reducing agent was added:

Stannous chloride

$\mathrm{ml}$

0.5

1.0

1.5

2.0

Phosphorus found in the solutions containing $\mathrm{P}$

$0.10 \mathrm{ppm}$
0.06
0.06
0.05
0.06

$0.25 \mathrm{ppm}$
0.19
0.18
0.17
0.17

$0.50 \mathrm{ppm}$

$1.00 \mathrm{ppm}$

0.41
0.39
0.36
0.38

0.89

0.88

0.82

0.85

Thus it seems as if the presence of ferrous iron would prevent the development of the colour maximum, its effect being the more intensive, the higher the amount of the reducing agent. Perhaps this could be explained on the basis of the supposition that under these conditions a partial reduction of phosphomolybdic acid to highly reduced colourless compounds occurs, the ferrous iron possibly acting as a catalyst. Also the lowering of the phosphorus values with the increase in the amount of stannous chloride added in the solutions containing ferric iron and $0.10 \mathrm{ppm}$ of phosphorus (cf. Table 1) could be explained on the basis of this hypothesis: at the lower oxidation-reduction potentials developed by the higher amounts of stannous chloride a part of the iron may be in the ferrous form and accelerate the formation of colourless phosphomolybdic compounds. If the phosphorus concentration of the solution was higher than $0.10 \mathrm{ppm}$ this decrease in the estimated phosphorus values by the increase of the amount of stannous chloride did not appear, probably, because the higher concentration of phosphomolybdic acid prevented the development of a too low oxidation-reduction potential.

It is probable, however, that this explanation for the interference of iron in the development of molybdenum blue is too simple. For example, it has been found $(1,2)$ that the time elapsed between the additions of molybdate and stannous chloride was an important factor when the solutions contained ferrous iron. Only when the reducing agent was added immediately after the application of the molybden reagent no effect of ferrous iron could be detected, but even an interval of one minute was sufficient to let $1 \mathrm{ppm}$ of ferrous iron definitely inhibit the colour development. In the experiments reported above this interval was about ten minutes.

The fact that the interfering ferrous iron must have time to react with the phosphomolybdic acid or molybdic acid before they are reduced, points at the possibility of complex formation of some kind which would prevent the normal reduction of phosphomolybdic acid to molybdenum blue. This supposition was 
corroborated by the observation that ferrous iron, at least up to $50 \mathrm{ppm}$, did not cause any error when added to a phosphorus solution already reduced, not even when the readings were taken 45 minutes after the addition of ferrous iron.

Thus the effect of ferric and ferrous iron upon the development of molybdenum blue seems to be a fairly complicated problem. Although it can be explained, partly at least, on the basis of the influence of these ions upon the oxidationreduction potential of the system, the elimination of their interference is not quite simple. A too low oxidation-reduction potential may lead to similar errors as a too high potential, probably due to a partial reduction of the phosphomolybdic acid to highly reduced colourless compounds in the former case, and to the oxidation of the blue complexes in the latter case. An increase in the amount of stannous ions is useful for ferric iron solutions of high phosphorus concentration, but increases the error if the phosphorus concentration is low. According to the results reported above, the dilution of the solutions containing ferric iron often gives more reliable results than the increase in the reducing agent. The reduction of ferric iron to ferrous form may lead to serious errors.

\section{The concentrations of acid and molybdate}

It is a well known fact that the concentrations of acid and molybdate exert an essential effect upon the development, intensity, and stability of molybdenum blue in phosphate solutions. In this respect, the ratio between the molybdate concentration and the acidity is the most important factor. It seemed probable that also the iron interference could be influenced by the composition of the molybdate reagent.

To study this problem experiments were carried out in which the effect of ferric and ferrous iron upon the development of molybdenum blue at various concentrations of phosphorus, sulphuric acid, and ammonium molybdate was examined. The volume of the solution to be reduced was $25 \mathrm{ml}$. The reduction was performed by stannous chloride solution prepared by dissolving $100 \mathrm{mg}$ of tin paper in $1 \mathrm{ml}$ of concentrated hydrochloric acid, and diluting the solution up to $20 \mathrm{ml}$. $1 \mathrm{ml}$ of this reagent, corresponding to 0.08 me of stannous tin was added to the $25 \mathrm{ml}$ to be reduced. This amount of stannous tin was considerably higher than that used by Truog and Meyer (6). If not otherwise mentioned, the readings were taken 15 minutes after the reduction.

In these experiments the concentrations of ammonium molybdate varied from 0.7 to $1.2 \mathrm{mg} / \mathrm{ml}$ in solutions of $0.4 \mathrm{~N}$ sulphuric acid, from 1.2 to $2.7 \mathrm{mg} / \mathrm{ml}$ in solutions of $0.6 \mathrm{~N}$ sulphuric acid, and from 2.4 to $4.4 \mathrm{mg} / \mathrm{ml}$ in the solutions of $0.8 \mathrm{~N}$ sulphuric acid. The phosphorus concentrations chosen were $0.10,0.25$, 0.50 , and $2.00 \mathrm{ppm}$.

In the numerous series of measurements performed some general trends could be detected. The data presented in Table 2 give a typical picture of the effect of ferric iron upon the determination of phosphorus. In these series iron was applied as ferric nitrate, but the results obtained when ferric sulphate was used were equal 
Table 2. Phosphorus found at various concentrations of acid and molybdate in solutions containing ferric iron. P concentration $0.50 \mathrm{ppm}$.

\begin{tabular}{|c|c|c|c|c|c|c|c|}
\hline \multirow{6}{*}{$0.4 \mathrm{~N} \mathrm{H}_{2} \mathrm{SO}_{4}$} & \multirow{2}{*}{$\begin{array}{l}\text { Ferric iron } \\
\text { ppm }\end{array}$} & \multicolumn{6}{|c|}{ Ammonium molybdate $\mathrm{mg} / \mathrm{ml}$} \\
\hline & & 0.7 & 0.8 & 0.9 & 1.0 & 1.1 & 1.2 \\
\hline & 25 & 0.53 & 0.52 & 0.50 & 0.50 & 0.49 & 0.49 \\
\hline & 50 & 0.53 & 0.52 & 0.49 & 0.48 & 0.46 & 0.46 \\
\hline & 100 & 0.52 & 0.51 & 0.49 & 0.46 & 0.43 & 0.42 \\
\hline & 150 & 0.51 & 0.50 & 0.47 & 0.44 & 0.40 & 0.39 \\
\hline \multirow{6}{*}{$0.6 \mathrm{~N} \mathrm{H}_{2} \mathrm{SO}_{4}$} & Ferric iron & \multicolumn{6}{|c|}{ Ammonium molybdate $\mathrm{mg} / \mathrm{ml}$} \\
\hline & ppm & 1.2 & 1.5 & 1.8 & 2.1 & 2.4 & 2.7 \\
\hline & 25 & 0.52 & 0.52 & 0.51 & 0.49 & 0.45 & 0.42 \\
\hline & 50 & 0.54 & 0.52 & 0.50 & p.46 & 0.42 & 0.38 \\
\hline & 100 & p. 54 & 0.52 & 0.49 & 0.45 & 0.39 & 0.32 \\
\hline & 150 & 0.55 & 0.52 & 0.49 & 0.45 & 0.38 & 0.29 \\
\hline \multirow{6}{*}{$0.8 \mathrm{~N} \mathrm{H}_{2} \mathrm{SO}_{4}$} & Ferric iron & \multicolumn{6}{|c|}{ Ammonium molybdate $\mathrm{mg} / \mathrm{ml}$} \\
\hline & ppm & 2.4 & 2.8 & 3.2 & 3.6 & 4.0 & 4.4 \\
\hline & 25 & 0.52 & 0.51 & 0.51 & 0.50 & 0.47 & 0.44 \\
\hline & 50 & 0.52 & 0.51 & 0.50 & 0.49 & 0.45 & 0.40 \\
\hline & 100 & 0.53 & 0.51 & 0.50 & 0.47 & 0.43 & 0.37 \\
\hline & 150 & 0.54 & 0.52 & 0.50 & 0.47 & 0.40 & 0.31 \\
\hline
\end{tabular}

to these. In all the acid concentrations an increase in the ammonium molybdate concentration, or in the ratio of molybdate to acid appeared to influence the iron interference almost equally. At the lowest molybdate concentrations ferric iron tended to increase the phosphorus values, often the more the higher the iron concentration. In the highest molybdate concentrations a decrease in the phosphorus values was detected, this decrease being the higher the higher the iron content of the solution. Between the molybdate concentrations causing these contrary effects of iron some concentration in which the iron interference appeared to be almost negligible even in as high a concentration of iron as $150 \mathrm{ppm}$ could be found. According to these and other data, these fairly "ideal" concentrations of molybdate were about $0.8 \mathrm{mg} / \mathrm{ml}$ in $0.4 \mathrm{~N}$ acid, $1.8 \mathrm{mg} / \mathrm{ml}$ in $0.6 \mathrm{~N}$ acid, and $3.2 \mathrm{mg} / \mathrm{ml}$ in $0.8 \mathrm{~N}$ acid. If reported as the ratios of molybdate $(\mathrm{mg} / \mathrm{ml})$ to acid $(\mathrm{N})$ these values correspond to 2 in $0.4 \mathrm{~N}$ acid, 3 in $0.6 \mathrm{~N}$ acid, and 4 in $0.8 \mathrm{~N}$ acid. In $0.5 \mathrm{~N}$ acid it was 2.5 , and in $0.7 \mathrm{~N}$ acid 3.5. Consequently, there is a distinct regularity in these ratios, obviously connected with the general equilibration of the molybdenum blue reaction under these conditions.

The phosphorus concentration tended to exert an effect upon the level of the most suitable molybdate concentration. Generally, a higher ratio of molybdate to acid was desirable in the higher phosphorus concentrations than in the lower ones. 
Therefore, it is not possible to find a ratio which would totally eliminate the iron interference at all the phosphorus concentrations. Besides, there seems to be several factors, e.g. the temperature, the interval between the reduction and the taking of the readings, etc. that lead to a certain variation in the level of the best molybdate concentration. For example, the longer the interval between the reduction and the taking of the readings the lower is the best molybdate concentration.

Fairly good results may be obtained by adjusting the ratio of molybdate and acid as can be proved e. g. by the following results. The solution to be reduced was $0.8 \mathrm{~N}$ sulphuric acid and contained ammoniummolybdate $3.2 \mathrm{mg} / \mathrm{ml}$. The readings were taken 15 minutes and 60 minutes after the reduction. The values for phosphorus found at the presence of various concentrations of ferric iron were as follows:

Ferric iron

ppm

$\begin{array}{ccccc}0 & 0.10 & 0.25 & 0.50 & 1.00 \\ 1 & 0.11 & 0.26 & 0.51 & 1.02 \\ 3 & 0.10 & 0.26 & 0.51 & 1.03 \\ 5 & 0.10 & 0.26 & 0.51 & 1.03 \\ 7.5 & 0.10 & 0.26 & 0.50 & 1.04 \\ 10 & 0.10 & 0.26 & 0.50 & 1.04 \\ 25 & 0.09 & 0.25 & 0.50 & 1.04 \\ 50 & 0.08 & 0.25 & 0.50 & 1.05 \\ 100 & 0.08 & 0.25 & 0.50 & 1.06 \\ 150 & 0.08 & 0.26 & 0.51 & 0.86 \\ 200 & 0.07 & 0.26 & 0.51 & 0.79\end{array}$

15 minutes

0.79
60 minutes

$\begin{array}{llll}0.10 & 0.25 & 0.50 & 1.00 \\ 0.11 & 0.26 & 0.50 & 1.00 \\ 0.10 & 0.25 & 0.49 & 1.00 \\ 0.10 & 0.25 & 0.49 & 0.99 \\ 0.10 & 0.25 & 0.49 & 0.99 \\ 0.10 & 0.24 & 0.48 & 0.98 \\ 0.09 & 0.23 & 0.47 & 0.97 \\ 0.08 & 0.23 & 0.46 & 0.97 \\ 0.07 & 0.22 & 0.46 & 0.97 \\ 0.05 & 0.20 & 0.45 & 0.94 \\ 0.03 & 0.19 & 0.41 & 0.84\end{array}$

The most balanced systems appeared to be those with a phosphorus concentration of $0.25-0.50 \mathrm{ppm}$. Even $200 \mathrm{ppm}$ of iron did not cause an error higher than $0.01 \mathrm{ppm}$ according to the readings taken after 15 minutes. After 60 minutes the fading effect of iron could be detected in considerably lower iron concentrations, but even then the errors were markedly lower than those generally reported. A rapid fading, known to be characteristic of the iron interference could not be detected in the colour of these solutions, provided the iron concentration was not higher than $100 \mathrm{ppm}$. It is of interest to notice that the same amounts of iron $(25-100 \mathrm{ppm})$ that caused an increase in the phosphorus values of the solutions containing $1.00 \mathrm{ppm}$ exerted a fading effect upon the $0.10 \mathrm{ppm}$ values when measured 15 minutes after the reduction.

The results obtained when the amount of stannous chloride was only one half of that applied in the series reported above also indicated that ferric iron up to a concentration of $50 \mathrm{ppm}$ did not cause any fading of the colour. On the contrary, the phosphorus values found were even somewhat higher than those of the former series, both when the readings were taken after 15 minutes and 60 minutes. Thus, it was not only the high amount of reducing agent that prevented the fading effect of iron. In some other series, the increase in the phosphorus values due to lower concentrations of iron was, within certain limits, the higher the lower the amount of stannous chloride applied. At higher iron level the lower amounts of stannous chloride could not prevent a marked fading of the colour. 
To sum up, on the basis of these results it seems to be possible largely to eliminate the interference caused by ferric iron, even when it is present in rather high concentrations, $100-150 \mathrm{ppm}$. In practice the solutions used for the colorimetric determination of phosphorus seldom contain iron more than $25 \mathrm{ppm}$, generally the iron concentration is much lower. By a proper choice of the acid and molybdate concentrations of the reagent and of the amount of stannous chloride applied, the method can be made quite reliable within the phosphorus and iron concentrations most frequent in the solutions to be analysed. The ratio between molybdate and acid in the solution to be reduced is a most important factor in this respect. In the experiments performed the best results were obtained when the ratio of ammonium molybdate, expressed as $\mathrm{mg} / \mathrm{ml}$, to sulphuric acid, expressed as normality, was five times as high as the acidity, expressed as normality. It can be mentioned that in the original method by Truog and Meyer (6) the ratio is 2.5 and the acid $0.4 \mathrm{~N}$. Because it is higher than the "most suitable" ratio for $0.4 \mathrm{~N}$ acid, the presence of ferric iron generally, decreases the colour intensity. At lower ratios of molybdate to acid ferric iron causes an increase in the colour intensity. Yet, it somewhat depends on the amount of stannous tin applied how evident these phenomena are, and also the phoshorus and iron concentrations play their role. At a very high iron content the fading of the colour is inevitable.

The interfering effect of ferrous iron was more difficult to avoid than that of ferric iron. No changes in the concentrations of molybdate and acid eliminated the fading or the prevention of the colour development in the presence of ferrous iron, when sulphuric acid was used. But if hydrochloric acid was substituted for sulphuric acid the effect of ferrous iron upon the density values was found to become an opposite one. This increase in the colour intensity in the presence of ferrous iron was rather low, corresponding to $0.02 \mathrm{ppm}$ of phosphorus, if the iron concentration was $5 \mathrm{ppm}$, and increased up to $0.05 \mathrm{ppm}$ of phosphorus, if the iron concentration was raised to $50 \mathrm{ppm}$ in a solution containing $0.50 \mathrm{ppm}$ of phosphorus. The interfering effect of ferrous iron was even more negligible, if one half of the acid in the solution was sulphuric acid.

Also the disturbing effect of ferric iron can be easily eliminated in solutions containing both sulphuric acid and hydrochloric acid. If e. g. the total acidity of the solution to be reduced was $0.8 \mathrm{~N}$, half in sulphuric acid, half in hydrochloric acid, and the molybdate concentration $3.2 \mathrm{mg} / \mathrm{ml}$, the ferric iron up to $40-50 \mathrm{ppm}$ did not interfere. Thus this mixture of acids in the molybdate reagent offers an available way to eliminate the disturbing effect of iron.

\section{$S u m m a r y$}

The interference of ferric and ferrous iron in the determination of phosphate by the molybdenum blue method has been studied. It was found that the presence of ferric iron in the solutions could cause either an increase or a decrease in the colour intensity depending on the amount of stannous chloride applied and on the 
acid and molybdate concentrations in the reagent. Also the phosphorus concentration exerted its effect upon the course of the errors.

If the original modification of TRUOG and MeYer was employed, generally, the most convenient way for the elimination of the interference of ferric iron was to dilute the solution. An increase in the amount of stannous chloride largely helped to prevent the fading effect of ferric iron, provided the phosphorus concentration was not lower than $0.25 \mathrm{ppm}$.

When the effect of ferric iron upon the development of molybdenum blue at various concentrations of sulphuric acid and ammonium molybdate was studied, the observation was made that at each acidity there could be found a concentration of molybdate in which the effect of even fairly high amounts of ferric iron was almost negligible. In lower molybdate concentrations the presence of ferric iron caused an increase in the colour intensity, in higher molybdate concentrations the fading effect of ferric iron was marked. This most suitable level of the molybdate concentration depended to a certain degree on the phosphorus concentration of the solution and on the amount of stannous chloride applied. Fairly good results could be obtained, if the ratio of molybdate (expressed as $\mathrm{mg} / \mathrm{ml}$ ) to acid (expressed as normality) in the solution to be reduced was five times as high as the acidity of the solution to be reduced (expressed as its normality), e.g. 4 in $0.8 \mathrm{~N}$ acid, 3.5 in 0.7 $\mathrm{N}$ acid, 3 in $0.6 \mathrm{~N}$ acid etc.

Although it seemed to be fairly possible to avoid the interference of ferric iron by a proper choice of the concentrations of acid and molybdate and of the amount of stannous chloride applied, the fading effect of ferrous iron could not be prevented, if only sulphuric acid was used in the reagents. But the substitution of sulphuric acid by hydrochloric acid totally prevented the fading effect of ferrous iron. On the contrary, a slight increase in the colour intensity was demonstrated. This was true also when only one half of the acid present was hydrochloric acid. It was found that this mixture of sulphuric acid and hydrochloric acid in the molybdate reagent offers an available way for the elimination of the disturbing effect of iron.

\section{REFERENCES}

(1) Chapman, H. D. 1932. Studies on the blue colorimetric method for the determination of phosphorus. Soil Sci., 33, p. 125-134.

(2) Dyer, W. J. and Wrenshall, C. L. 1938. An improved method for the determination of phosphate by photoelectric colorimetry. Canad. J. Res., B 16, p. $97-108$.

(3) Eisenberger, E. and Przybylski, H. F. 1940. Mikrokolorimetrische Bestimmung der Phosphorsäure in eisenhaltigen Bodenauszügen. Bodenk. u. Pflanzenern., 17, p. 252-264.

(4) Smith, G. R., Dyer, W. J., Wrenshall, C. L., and DeLong, W. A. 1939. Further observations. on the determination of Phosphate by photoelectric colorimetry. Canad. J. Res., B 17, p. $178-191$.

(5) Tischer, J. 1934. Über die Bestimmung der phosphorsäure mittels der Phosphor-MolybdenblauMethode und deren Anwendung auf Pflanzenaschen. Zeitschr. Pflanzenern., Düng. u. Bodenk., A 33, p. 192-242. 
(6) Truog, E. and Meyer, A. H. 1929. Improvements in the Denigès colorimetric method for phosphorus and arsenic. Ind. Eng. Chem., Anal. Ed., 1, p. 136-139.

(7) Tschopp, E. and Tschopp, E. 1932. Reduktion der Phosphormolybdänsäure zu Molybdenblau. Helv. Chim. Acta, 15, p. 793.

(8) WARD, R. 1933. The colorimetric determination of phosphorus in citric acid extracts of soils. Soil Sci., 35, p. $85-97$.

(9) Warren, R. G. and Pugh, A. J. 1930. The colorimetric determination of phosphoric acid in hydrochloric acid and cifric acid extracts of soils. J. Agr. Sci., 20. p. 532-540.

\title{
SELOSTUS:
}

\section{RAUTA FOSFAATIN MÄ̈RITYSTÄ HÄIRITSEVÄNÄ TEKIJÄNÄ MOLYBDENISINI- MENETELMÄSSÄ}

\author{
ARMI KAILA
}

Yliopiston maanviljelyskemian laitos, Helsinki

Jo pienetkin määrät rautaa vaikuttavat tavallisesti värin muodostusta estävästi tai väriä vaalentavasti useimmissa molybdenisinireaktioon perustuvissa fosfaatin määritysmenetelmissä. Edellä olevassa tutkimuksessa on yritetty selvittää, voidaanko raudan häiritsevää vaikutusta estää muuttamalla reagenssien määrää ja koostumusta.

Truogin ja Meyerin (6) menetelmää käytettäessä todettiin tutkittavan, ferri-rautaa sisältävän liuoksen laimentamisen olevan edullisinta. Myös stannokloridin määrän lisääminen vähensi huomattavasti raudan häiritsevää vaikutusta, yleensä suhteellisesti sitä enemmän mitä suurempi oli liuoksen fosforinväkevyys. Kun liuoksessa oli fosforia vain $0.10 \mathrm{mg} / 1$, mitatut fosforin arvot olivat sitä matalampia, mitä suurempi oli lisätyn stannokloridin määrä ja mitä enemmän rautaa oli liuoksessa. Tämän ilmiön arveltiin olevan yhteydessä ferro-raudan erittäin voimakkaan väriä vaalentavan vaikutuksen kanssa, jonka oletettiin johtuvan fosforimolybdenihappokompleksin pelkistymisestä näissä olosuhteissa osaksi aina värittömiksi yhdisteiksi asti. Toisaalta todettiin kuitenkın, että ferro-raudan väriä vaalentava vaikutus ilmeni vain silloin, kun molybdaattireagenssia sisältävä liuos sai seistä jonkin aikaa ennen pelkistämistä. Jo pelkistettyyn liuokseen lisätty ferro-rauta ei vaikuttanut väriä vaalentavasti edes 45 minuutin kuluessa. Näin ollen raudan vaikutus ei ole selitettävissä yksinomaan systeemin hapetus-pelkistyspotentiaalin muutosten perusteella.

Tutkittaessa ferri-raudan vaikutusta molybdenisisen muodostumiseen liuoksen rikkihapon ja ammoniummolybdaatin väkevyyksien vaihdellessa havaittiin, että kutakin happamuusastetta varten voitiin löytää molybdaatin väkevyys, jota käytettäessä rauta ei häirinnyt sanottavasti. Jos molybdaatin väkevyys oli tätä suurempi, rauta alensi värin intensiteettiä, jos taas molybdaatin väkevyys oli tätä pienempi, rauta tummensi liuoksia. Fosforinpitoisuus ja stannokloridin määrä vaikuttivat jonkin verran tämän edullisimman molybdaattikonsentraation suuruuteen. Yleensä saatiin melko hyviä tuloksia, kun pelkistettävän liuoksen molybdaatin ( $\mathrm{mg} / \mathrm{ml}$ ) ja hapon (n) väkevyyksien suhde oli viisi kertaa niin suuri kuin happamuus ilmoitettuna normaalisuutena.

Ferro-raudan värin muodostusta estävää vaikutusta ei voitu välttää muuttamalla reagenssin hapon ja molybdaatin väkevyyttä. Mutta jos rikkihapon asemesta käytettiin suolahappoa tai vain puoletkin rikkihaposta korvattiin suolahapolla, ferro-rauta ei alentanut fosforin arvoja, vaan päin vastoin kohotti niitä jonkin verran.

Myös ferri-raudan häiritsevä vaikutus on helposti vältettävissä, kun käytetään rikkihapon ja suolahapon seosta. Esimerkiksi kokonaishappamuudeltaan $0.8 \mathrm{n}$ liuoksessa, jossa puolet haposta oli rikkihappoa, puolet suolahappoa, ja molybdaatin väkevyys $3.2 \mathrm{mg} / \mathrm{ml}$, ei edes $40-50 \mathrm{mg}$ ferri-rautaa litraa kohti vaikuttanut lainkaan fosforin arvoihin. 